\title{
Hepatitis C Screening: Barriers to Linkage to Care
}

\author{
Sammy Saab*1,2, Youssef P. Challita ${ }^{1}$, Lisa M. Najarian ${ }^{1}$, Rong Guo ${ }^{3}$, Satvir S. Saggi ${ }^{1}$ \\ and Gina $\mathrm{Choi}^{1,2}$
}

${ }^{1}$ Departments of Surgery, University of California at Los Angeles, Los Angeles, CA, USA; ${ }^{2}$ Departments of Medicine, University of California at Los Angeles, Los Angeles, CA, USA; ${ }^{3}$ Departments of Medicine Statistics Core, University of California at Los Angeles, Los Angeles, CA, USA

\begin{abstract}
Background and Aims: Hepatitis C (HCV) is a medical and public health concern. Once infected individuals are identified, management includes not only education but also the use of antiviral therapy. Although screening for HCV is readily available, barriers exist which prevent assessment and treatment in individuals potentially infected with HCV. Methods: This is a retrospective study of patients screened for HCV within the University of California, Los Angeles Health Care System between February 22 and July 9, 2018. We defined linkage to care as: 1) confirmatory HCV RNA test after screening HCV antibody test found a positive result; and 2) follow-up appointment for treatment was established with a specialist. Demographic and baseline laboratory values were collected. Factors potentially associated with prohibiting linkage of care were evaluated. Results: During the study period, 17,512 individuals were screened for HCV. A total of $238(1.35 \%)$ were found to have detectable HCV antibodies. Of the individuals with detectable HCV antibodies, 48 (20\%) did not undergo confirmatory testing with viral levels. Of the 190 individuals who underwent further testing, 70 patients were noted to be viremic. Among them, 17 of the 70 (24\%) were not linked to a specialist for further care. Younger patients ( $p=$ 0.02 ) and people who inject drugs $(p=0.02)$ were less likely to be referred for specialty care. Conclusions: The results of our study highlight that younger patients and people who inject drugs are less likely to be referred to specialty care for HCV treatment. Efforts are needed to engage these populations.

Citation of this article: Saab S, Challita YP, Najarian LM, Guo R, Saggi SS, Choi G. Hepatitis C screening: Barriers to linkage to care. J Clin Transl Hepatol 2019;7(3):226-231. doi: 10.14218/JCTH.2018.00063.
\end{abstract}

\section{Introduction}

Hepatitis $C$ is a viral infection with significant hepatic and extra-hepatic manifestations. ${ }^{1}$ Not only is hepatitis $\mathrm{C}$ a common cause of cirrhosis, it is a major risk factor for hepatocellular carcinoma and one of the leading indications for

\section{Keywords: Hepatitis C; Screening; Linkage.}

Abbreviations: $\mathrm{CI}$, confidence interval; $\mathrm{HCV}$, hepatitis $\mathrm{C}$ virus; IQR, interquartile range; PWID, people who inject drugs.

Received: 13 December 2018; Revised: 4 February 2019; Accepted: 1 March 2019

*Correspondence to: Sammy Saab, Pfleger Liver Institute, UCLA Medical Center, 200 Medical Plaza, Suite 214, Los Angeles, CA 90095, USA. Tel: +1-310-2066705, Fax: +1-310-206-4197, E-mail: SSaab@mednet.ucla.edu liver transplantation. ${ }^{2}$ Moreover, its extra-hepatic manifestations include varied expressions of glomerulonephritis, cryoglobulinemia, and lymphoma. ${ }^{3-5}$

The largest cohort of individuals infected with hepatitis $C$ virus (HCV) are the baby-boomers, people born between the years 1945 and 1965.6 Although there are multiple risk factors for this blood-borne infection, many individuals may have been infected through blood transfusions before HCV was identified and blood products were screened for the virus. ${ }^{7}$ Thus, a significant number of infected individuals are unaware of their infection status. ${ }^{8}$ The treatment of HCV has evolved from therapies that were associated with significant adverse effects to the development of all-oral direct acting therapies that are highly effective, safe, and tolerable. ${ }^{9}$ Consequently, major health care societies recommend screening patients for HCV based on their age, in addition to risk factors and recommended therapy to all infected individuals regardless of severity of fibrosis as long as their prognosis is at least 1 year. ${ }^{10}$ Identifying those infected is the first step toward the elimination of $\mathrm{HCV}^{11,12}$

There is a cascade of events that begin with identifying $\mathrm{HCV}$ infected individuals and continue toward treatment. The biggest limitation appears to be identifying those infected. ${ }^{13}$ Screening for HCV relies on testing for antibodies of the virus and then confirming the presence of infection by measuring the viral load. After HCV infection is confirmed, patients should be linked to care with a provider experienced in treating $\mathrm{HCV}^{10}$ However, there are a number of limitations that can exist in every stage of care. The hypothesis of our study is that most barriers to HCV treatment are modifiable. We reviewed the cascade of events following screening for $\mathrm{HCV}$ in order to identify barriers for linking patients infected with HCV to care.

\section{Methods}

\section{Screening}

All patients found to have detectable HCV antibodies for hepatitis $C$ at the University of California, Los Angeles Healthcare System during the study period between February and July 2018 were identified using an administrative database. ${ }^{14}$ Ordering providers were alerted of the results by the laboratory. We also contacted providers of patients with positive enzyme-linked immunosorbent assay results. Our coordinator recommended additional laboratory testing in the form of an HCV RNA quantitative PCR with reference to genotype and offered to facilitate a clinic appointment with a Hepatologist. 


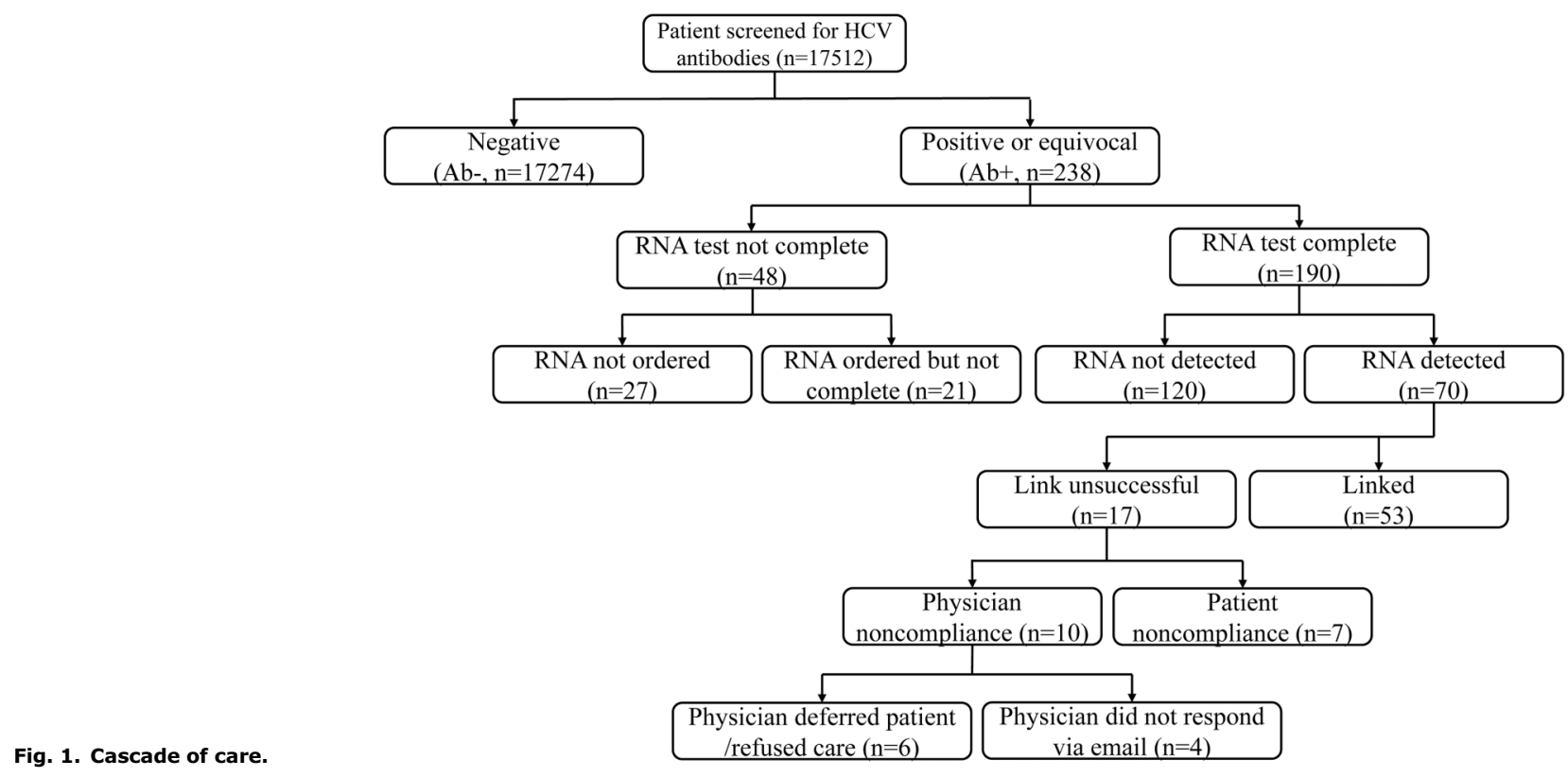

We collected data on patients' age, gender, health insurance type, health care setting of antibody screening, home zip code, homeless status, injection drug usage and laboratory test results. The zip code was used to estimate the patients' socioeconomic status. ${ }^{15}$ We also recorded the time between antibody and RNA testing, and the number of emails sent to the primary providers until a response was obtained. The health care setting was stratified according to whether testing occurred during hospitalization, emergency department visit, or clinic visit. Clinics were further stratified if there were single specialty (by Primary Care Providers) or multispecialty (not including Gastroenterology or Hepatology physicians).

Table 1. Overall demographics and hepatitis $\mathrm{C}$ viral load assessment

\begin{tabular}{llll}
\hline Variable not tested & Total, $n=238$ & HCV RNA tested, $n=190$ & HCV RNA, $n=48$ \\
\hline Median age (IQR), years & $59(47-66)$ & $59(46-66)$ & $61(51-67)$ \\
$\begin{array}{l}\text { Gender - M/F, \% } \\
\text { Insurance type }\end{array}$ & $150 / 88(63 / 37 \%)$ & $118 / 72(62 / 38 \%)$ & $32 / 16(67 / 33 \%)$ \\
$\quad$ Private & $97(40 \%)$ & $81(43 \%)$ & $16(33.3 \%)$ \\
$\quad$ Medicare & $59(25 \%)$ & $45(24 \%)$ & $14(29.2 \%)$ \\
HMO & $59(25 \%)$ & $45(24 \%)$ & $14(29.2 \%)$ \\
Medi-Cal & $19(8 \%)$ & $16(8 \%)$ & $3(6.3 \%)$ \\
$\quad$ No insurance & $4(2 \%)$ & $3(1 \%)$ & $1(2 \%)$ \\
Health care setting & & & $15(31 \%)$ \\
Hospital & $84(35 \%)$ & $69(36 \%)$ & $3(6 \%)$ \\
ER & $17(7 \%)$ & $14(7 \%)$ & $14(29 \%)$ \\
Clinic & & & $16(33 \%)$ \\
Single specialty & $65(27 \%)$ & $51(27 \%)$ & $7.4(3.6-30.8)$ \\
Multispecialty & $72(30 \%)$ & $56(30 \%)$ & $\$ 71(55 \mathrm{k}-90)$ \\
Median distance (IQR), miles $\dagger$ & $9.0(3.6-24.3)$ & $9.3(3.6-22.8)$ & $8(17 \%)$ \\
Median household income (IQR), thousand & $\$ 72(53 \mathrm{k}-86)$ & $\$ 72(51 \mathrm{k}-86)$ & $6(13 \%)$ \\
Homeless & $34(14 \%)$ & $26(14 \%)$ & $27(14 \%)$ \\
PWID & $33(14 \%)$ & & \\
\hline
\end{tabular}

Abbreviations: IQR, interquartile range; HCV, hepatitis C virus; yrs, years; M/F, male/female; HMO, Health Maintenance Organization; ER, emergency room; PWID, people who inject drugs. $\dagger$ Distance from home to clinic. 
Saab S. et al: Barriers to HCV care

Table 2. Median laboratory values of hepatitis $\mathrm{C}$ antibody-positive patients

\begin{tabular}{llll}
\hline Variable & Total, $n=238$ & HCV RNA tested, $n=190$ & HCV RNA not tested, $n=48$ \\
\hline Platelet count (IQR), $1 / \mathrm{L}$ & $221(182-279)$ & $218(178-279)$ & $228(194-278)$ \\
AST (IQR), U/L & $28(19-44)$ & $28(19-45)$ & $28(20-37)$ \\
ALT (IQR), U/L & $25(17-49)$ & $25(16-50)$ & $32(18-43)$ \\
Total bilirubin (IQR), mg/dL & $0.4(0.3-0.7)$ & $0.4(0.3-0.7)$ & $0.6(0.3-0.7)$ \\
APRI (IQR) & $0.3(0.2-0.5)$ & $0.3(0.2-0.6)$ & $0.3(0.2-0.4)$ \\
\hline
\end{tabular}

IQR, interquartile range; AST, aspartate aminotransferase; ALT, alanine aminotransferase; U, units; HCV, hepatitis C Virus; APRI, AST to platelet ratio index.

Successful linkage to care was assessed in two separate ways: 1 ) if the patient underwent testing for RNA (testing linkage); and 2) if the patient was referred to a hepatitis $C$ specialist if they were viremic (specialty linkage). Patients were given 3 weeks from their positive antibody result to undergo HCV RNA testing. Patients who tested for HCV viremia within the 3 -week period met the criteria for successful testing linkage to care. Barriers to linkage of care were recorded for both assessments.

\section{Statistics}

Outcomes at both the testing linkage and specialty linkage levels were assessed. Standard descriptive analyses, median (interquartile range $[\mathrm{IQR}]), n(\%)$, and univariate analysis were conducted using Microsoft Excel 15.2 (Microsoft, Seattle, WA, USA) by testing linkage or specialty linkage. Further analysis was conducted in the form of chi-squared, Fischer's exact tests, and multivariate logistic regression using the Statistical Analysis Software version 9.4 (SAS Institute Inc., Cary, NC, USA).

\section{Results}

A total of 17,512 patients were screened during the study period, among whom 238 were found to have detectable HCV antibodies (Fig. 1). The median (IQR) age of patients found to be HCV antibody positive was 59 (47-66) years (Table 1 ). Most of the patients were male and had commercial insurance. Most of the patients were tested in primary or multispecialty clinics, and lived within 10 miles of the site of testing. Few patients were homeless or people who inject drugs (PWID). Median (IQR) liver-associated factors and platelet test results are shown in Table 2. The median (IQR) aspartate aminotransferase to platelet ratio index was 0.3 (0.2-0.5).

A total of 190 (79\%) out of the 238 patients with detectable HCV antibodies were further assessed for HCV viremia, of which $70(37 \%)$ had detectable viral levels.

Table 3. Demographics of patients referred and not referred to specialty care

\begin{tabular}{lll}
\hline Variable & Referred, $n=53$ & Not referred, $n=17$ \\
\hline Median age (IQR) & 60 yrs (49-67) & 48 yrs $(30-58)$ \\
Gender - M/F (\%) & $33 / 20(62 \% / 38 \%)$ & $11 / 6(65 \% / 35 \%)$ \\
Insurance type & & $6(35 \%)$ \\
$\quad$ Private & $24(45 \%)$ & $2(12 \%)$ \\
Medicare & $13(25 \%)$ & $7(41 \%)$ \\
HMO & $9(17 \%)$ & $2(12 \%)$ \\
Medi-Cal & $7(13 \%)$ & 0 \\
No insurance & 0 & $8(46 \%)$ \\
Medical setting & & $4(24 \%)$ \\
Hospital & $23(43 \%)$ & $1(6 \%)$ \\
ER & $3(6 \%)$ & $4(24 \%)$ \\
Clinic & & $8.9(3.5-18.0)$ \\
Single specialty & $13(25 \%)$ & $\$ 57(56-73)$ \\
Multispecialty & $14(26 \%)$ & $6(35 \%)$ \\
Distance from home to clinic (IQR), miles & $3.6(3.4-15.9)$ & $8(47 \%)$ \\
Median household income (IQR), thousand & $\$ 72(51-82)$ & $8(15 \%)$ \\
Homeless & $9(17 \%)$ & \\
PWID & & \\
\hline
\end{tabular}

Abbreviations: IQR, interquartile range; yrs, years; M/F, male/female; HMO, Health Maintenance Organization; ER, emergency room; PWID, people who inject drugs. 
Table 4. Median laboratory values according to specialty referral in hepatitis $\mathrm{C}$ viremic patients

\begin{tabular}{|c|c|c|}
\hline Variable & $\begin{array}{l}\text { Referred, } \\
n=53\end{array}$ & $\begin{array}{l}\text { Not referred, } \\
n=17\end{array}$ \\
\hline $\begin{array}{l}\text { Platelet count } \\
\text { (IQR), 1/L }\end{array}$ & $204(175-259)$ & $256(183-270)$ \\
\hline AST (IQR), U/L & $38(29-53)$ & $35(26-63)$ \\
\hline ALT (IQR), U/L & $40(22-61)$ & $39(24-75)$ \\
\hline $\begin{array}{l}\text { Total bilirubin (IQR), } \\
\mathrm{mg} / \mathrm{dL}\end{array}$ & $0.5(0.3-0.8)$ & $0.5(0.3-0.8)$ \\
\hline APRI (IQR) & $0.4(0.3-0.6)$ & $0.3(0.2-0.5)$ \\
\hline
\end{tabular}

Abbreviations: IQR, interquartile range; AST, aspartate aminotransferase; ALT alanine aminotransferase; $U$, Units; HCV, hepatitis C virus; APRI, AST to platelet ratio index.

Forty-eight patients with detectable HCV antibodies did not undergo viral load testing. Of the 48 patients who did not undergo HCV RNA testing, the test was not ordered by the provider for 27 patients. For the remaining 21 of the 48 patients, the test was ordered but not completed by the patient. Demographic comparison of the patients who were and were not checked for HCV viremia is shown in Table 1, and laboratory results in Table 2 . There were no statistically significant differences in the demographics and lab results between these two groups.

A total of 53 out of the $70(75 \%)$ patients with HCV viremia were referred to specialty care for further treatment. Demographics and laboratory values of patients who were and were not referred for specialty care are shown in Tables 3 and 4 . Patients who were not referred for specialty care were younger (median age of 48 vs $60, p=0.02$ ), and more likely to be PWID $(8 / 17,47 \%$ vs $9 / 5317 \%, p=$ 0.02 ). In a multivariate logistic regression analysis including age and PWID as independent variables, the adjusted odds ratio for PWID was 0.31 ( $p=0.07,95 \%$ confidence interval [CI]: 0.09-1.09) and the adjusted odds ratio for age was 1.03 ( $p=0.09,95 \% \mathrm{CI}: 1.00-1.07)$. In addition, we examined the interaction between age and PWID; the interaction effect was not significant and thus excluded from the model $(p=0.50)$. The reasons provided by laboratory ordering providers for not referring are listed in Table 5 . The most common reason for lack of specialty care was that the patient did not attend the appointment.

Table 5. Failures in Linkage to care by specialty linkage definition, $n=17$

\begin{tabular}{ll}
\hline Unsuccessful linkage reasons & $n$ \\
\hline Physician deferred treatment & 6 \\
Upcoming kidney transplant & 1 \\
Primary care physician will proceed with treatment & 1 \\
Physician states patient will not follow through with & 3 \\
treatment & 1 \\
Patient fled facility & 4 \\
Physician did not respond to linkage request via email & 4 \\
Patient noncompliant to referral & 7 \\
\hline
\end{tabular}

\section{Discussion}

The results of this study highlight the disparity between HCV screening and linkage of care. In our study, approximately $27 \%$ of patients who were found to have detectable HCV antibodies were not linked to either further testing or specialty care. We identified barriers to care and offering suggestions to mitigate these limitations. The definition of linkage to care varies across studies. Studies have defined linkage as confirmatory HCV RNA testing in patients found to have HCV antibodies, ${ }^{16-19}$ referral to specialty clinics among viremic patients, ${ }^{8,20-29}$ or both. ${ }^{30-35}$ Two studies defined linkage to care as receiving HCV RNA testing, referral to specialty care and attending the first appointment with the specialist. ${ }^{36,37}$ Several studies defined linkage to care as attending the first appointment with a provider and starting viral treatment, ${ }^{38-40}$ whereas two studies defined linkage to care as being seen by a specialist. ${ }^{41-43}$ In our study we defined linkage separately so we can better understand the limitations of care.

$\mathrm{HCV}$ infection possesses a number of characteristics that make elimination feasible, including the lack of a non-human reservoir, easy diagnosis, and effective curative treatment. ${ }^{11}$ Indeed, the World Health Organization proposes that viral infection can be eliminated within the next two decades provided that the diagnosis rate is $90 \%$, the treatment rate is $80 \%$, and the curative rate is $90 \% .44,45$ However, the results of our study highlight barriers to HCV elimination. Not only are there significant deficiencies in screening in the $\mathrm{USA}^{46}$ but a major gap exists between the diagnosis and treatment. The results of our study, as well as of others, suggest that the biggest obstacle to curing infected patients is linkage of care. Concentrated efforts are essential to bridge the gap.

This study demonstrated the important predictors of lack of linkage to specialty care for hepatitis $C$ were being a young adult and a PWID. The odds of receiving specialty care decrease by $70 \%$ for PWID (odds ratio $=0.31,95 \% \mathrm{CI}$ : $0.087-1.099, p=0.07)$. Similarly, for every unit decrease in age (years) the odds of being linked to specialty care decreases by $3 \%$ (odds ratio $=1.032$, 95\% CI: $0.996-$ $1.072, p=0.09$ ). This finding is of particular concern as PWIDs likely represent one of the fastest growing cohorts of HCV infection in the USA. In fact, in over a dozen states in this country, the HCV prevalence among young individuals is as high or higher than among baby-boomers. ${ }^{47}$ If HCV elimination is truly a goal, we must better engage this population. Several proposals to include HCV linkage to care among PWID include utilization of a multidisciplinary approach, fostering better communication, and increasing awareness of the implications of HCV infection. $22,23,48$

There are several limitations to our study. The most important is its retrospective nature. For many of our patients who were not linked to care, the reasons could only be projected. Nevertheless, thorough review of the medical record and discussions with the primary providers important insights were provided. Another important limitation is that we could not exclude selective screening in our cohort. The current practice for screening involves an opt-in approach, whereby a provider is alerted that their patient is a babyboomer and should be considered for HCV screening, according to the Center for Disease Control guidelines. ${ }^{7}$ Moreover, providers also screened patients based on risk factors for viral hepatitis C. Nonetheless, our entire cohort of patients 
screened consisted of almost 18,000 patients. Another limitation is that our study cohort may not reflect the general population of patients with HCV. For instance, the viremic rate in patients with detectable HCV antibodies was $37 \%$, which is substantially lower than described by others in the literature. One possible reason is that patients with HCV antibodies, but undetectable HCV RNA viral levels, may have been previously treated. We do not think this accounts for a substantial number of our aviremic patients since in that situation there would be no medical indication for screening. Moreover, there has been a trend noted in the literature of lower viremic rates in screening programs. ${ }^{34}$ Another limitation to our study is that patients were not directly contacted for reasons for not following up with viral load testing or appointment for treatments. Prospective studies may help clarify additional patient level barriers than what we described in our retrospective study.

The results of our study highlight that deficiencies exist in extending HCV-related care in the fastest growing infected cohort in the USA, particularly for the young and PWID. For $\mathrm{HCV}$ elimination policy to be effective, these cohorts must be engaged.

\section{Acknowledgments}

The research described was supported by NIH/National Center for Advancing Translational Science (NCATS) UCLA CTSI Grant Number UL1TR001881.

\section{Conflict of interest}

The authors have no conflict of interests related to this publication.

\section{Author contributions}

Contributed to study concept and design (SS), acquisition of data (YPC, LMH, SSS), analysis and interpretation of data (SS, YPC, LMN, GC), drafting of the manuscript (SS, YPC), critical revision of the manuscript for important intellectual content (SS, YPC, GC), statistical analysis (RG, YPC), administrative, technical, or material support (SS), study supervision (SS, GC), and guarantor of the article (SS). All authors approved the final version of the manuscript.

\section{References}

[1] Webster DP, Klenerman P, Dusheiko GM. Hepatitis C. Lancet 2015;385: 1124-1135. doi: 10.1016/S0140-6736(14)62401-6

[2] Kim WR, Lake JR, Smith JM, Skeans MA, Schladt DP, Edwards EB, et al. OPTN/SRTR 2013 Annual Data Report: liver. Am J Transplant 2015;15 Suppl 2:1-28. doi: 10.1111/ajt.13197.

[3] Younossi Z, Park H, Henry L, Adeyemi A, Stepanova M. Extrahepatic manifestations of hepatitis C: A meta-analysis of prevalence, quality of life, and economic burden. Gastroenterology 2016;150:1599-1608. doi: 10.1053/j. gastro.2016.02.039.

[4] Negro F, Forton D, Craxì A, Sulkowski MS, Feld JJ, Manns MP. Extrahepatic morbidity and mortality of chronic hepatitis C. Gastroenterology 2015;149: 1345-1360. doi: 10.1053/j.gastro.2015.08.035.

[5] Wong RJ, Saab S, Ahmed A. Extrahepatic manifestations of hepatitis C virus after liver transplantation. Clin Liver Dis 2017;21:595-606. doi: 10.1016/j. cld.2017.03.013.

[6] Smith BD, Morgan RL, Beckett GA, Falck-Ytter Y, Holtzman D, Teo CG, et al. Recommendations for the identification of chronic hepatitis $C$ virus infection among persons born during 1945-1965. MMWR Recomm Rep 2012;61:1-32.

[7] Denniston MM, Jiles RB, Drobeniuc J, Klevens RM, Ward JW, McQuillan GM, et al. Chronic hepatitis $C$ virus infection in the United States, National Health and Nutrition Examination Survey 2003 to 2010. Ann Intern Med 2014;160: 293-300. doi: 10.7326/M13-1133.

[8] Castrejón M, Chew KW, Javanbakht M, Humphries R, Saab S, Klausner JD. Implementation of a large system-wide hepatitis $C$ virus screening and linkage to care program for baby boomers. Open Forum Infect Dis 2017;4: ofx109. doi: 10.1093/ofid/ofx109.

[9] Kohli A, Shaffer A, Sherman A, Kottilil S. Treatment of hepatitis C: a systematic review. JAMA 2014;312:631-640. doi: 10.1001/jama.2014.7085.

[10] Hepatitis C. guidance: AASLD-IDSA recommendations for testing, managing, and treating adults infected with hepatitis $C$ virus. Hepatology $2015 ; 62$ 932-954. doi: 10.1002/hep.27950.

[11] Saab S, Le L, Saggi S, Sundaram V, Tong MJ. Toward the elimination of hepatitis $C$ in the United States. Hepatology 2018;67:2449-2459. doi: 10 1002/hep.29685.

[12] World Health Organization. Combating hepatitis B and C to reach elimination by 2030 . Advocacy brief. Assessed May 2016. Available from: https://apps. who.int/iris/bitstream/handle/10665/206453/WHO_HIV_2016.04_eng.pdf ; jsessionid =95C4FA3F13009E69C8212FC46AF1F8BA?sequence $=1$.

[13] Moorman AC, Xing J, Ko S, Rupp LB, Xu F, Gordon SC, et al. Late diagnosis of hepatitis $C$ virus infection in the Chronic Hepatitis Cohort Study (CHeCS): Missed opportunities for intervention. Hepatology 2015;61:1479-1484. doi: $10.1002 /$ hep. 27365 .

[14] Chou R, Cottrell EB, Wasson N, Rahman B, Guise JM. Screening for hepatitis $C$ virus infection in adults: a systematic review for the U.S. Preventive Services Task Force. Ann Intern Med 2013;158:101-108. doi: 10.7326/00034819-158-2-201301150-00574.

[15] United States Census Bureau. 2012-2016 American community survey 5-year estimates. Available from: https://factfinder.census.gov/faces/tableservices/jsf/pages/productview.xhtml?src =bkmk.

[16] Young KL, Huang W, Horsburgh CR, Linas BP, Assoumou SA. Eighteen- to 30year-olds more likely to link to hepatitis $C$ virus care: an opportunity to decrease transmission. J Viral Hepat 2016;23:274-281. doi: 10.1111/jvh. 12489.

[17] Assoumou SA, Huang W, Horsburgh CR Jr, Drainoni ML, Linas BP. Relationship between hepatitis $C$ clinical testing site and linkage to care. Open Forum Infect Dis 2014;1:ofu009. doi: 10.1093/ofid/ofu009.

[18] Blackburn NA, Patel RC, Zibbell JE. Improving screening methods for hepatitis $\mathrm{C}$ among people who inject drugs: Findings from the HepTLC initiative 2012-2014. Public Health Rep 2016;131 Suppl 2:91-97. doi: 10 $1177 / 003335491613105214$.

[19] Geboy AG, Mahajan S, Daly AP, Sewell CF, Fleming IC, Cha HA, et al. High hepatitis $C$ infection rate among baby boomers in an urban primary care clinic: Results from the HepTLC initiative. Public Health Rep 2016;131 Suppl 2:49-56. doi: 10.1177/00333549161310S209.

[20] MacLean CD, Berger C, Cangiano ML, Ziegelman D, Lidofsky SD. Impact of electronic reminder systems on hepatitis $C$ screening in primary care. J Viral Hepat 2018;25:939-944. doi: 10.1111/jvh.12885.

[21] Franco RA, Overton ET, Tamhane AR, Forsythe JM, Rodgers JB, Schexnayder $\mathrm{JK}$, et al. Characterizing failure to establish hepatitis $C$ care of baby boomers diagnosed in the emergency department. Open Forum Infect Dis 2016;3: ofw211. doi: 10.1093/ofid/ofw211.

[22] Bajis S, Dore G], Hajarizadeh B, Cunningham EB, Maher L, Grebely J. Interventions to enhance testing, linkage to care and treatment uptake for hepatitis $C$ virus infection among people who inject drugs: A systematic review. Int J Drug Policy 2017;47:34-46. doi: 10.1016/j.drugpo.2017.07.002.

[23] Morano JP, Zelenev A, Lombard A, Marcus R, Gibson BA, Altice FL. Strategies for hepatitis $C$ testing and linkage to care for vulnerable populations: pointof-care and standard HCV testing in a mobile medical clinic. J Community Health 2014;39:922-934. doi: 10.1007/s10900-014-9932-9.

[24] Seña AC, Willis SJ, Hilton A, Anderson A, Wohl DA, Hurt CB, et al. Efforts at the frontlines: Implementing a hepatitis $C$ testing and linkage-to-care program at the local public health level. Public Health Rep 2016;131 Suppl 2:57-64. doi: 10.1177/00333549161310S210.

[25] Meyer JP, Moghimi Y, Marcus R, Lim JK, Litwin AH, Altice FL. Evidence-based interventions to enhance assessment, treatment, and adherence in the chronic Hepatitis C care continuum. Int J Drug Policy 2015;26:922-935. doi: 10.1016/j.drugpo.2015.05.002.

[26] Younossi ZM, LaLuna LL, Santoro JJ, Mendes F, Araya V, Ravendhran N, et al. Implementation of baby boomer hepatitis $\mathrm{C}$ screening and linking to care in gastroenterology practices: a multi-center pilot study. BMC Gastroenterol 2016;16:45. doi: 10.1186/s12876-016-0438-z.

[27] Tait JM, McIntyre PG, McLeod S, Nathwani D, Dillon JF. The impact of a managed care network on attendance, follow-up and treatment at a hepatitis C specialist centre. J Viral Hepat 2010;17:698-704. doi: 10.1111/j.13652893.2009.01227.x.

[28] Evon DM, Simpson KM, Esserman D, Verma A, Smith S, Fried MW. Barriers to accessing care in patients with chronic hepatitis $C$ : the impact of depression. Aliment Pharmacol Ther 2010;32:1163-1173. doi: 10.1111/j.1365-2036. 2010.04460.x. 
[29] Taylor BS, Hanson JT, Veerapaneni P, Villarreal R, Fiebelkorn K, Turner B]. Hospital-based hepatitis $C$ screening of baby boomers in a majority hispanic south texas cohort: Successes and barriers to implementation. Public Health Rep 2016;131 Suppl 2:74-83. doi: 10.1177/00333549161310S212.

[30] Falade-Nwulia O, Mehta SH, Lasola J, Latkin C, Niculescu A, O'Connor C, et al. Public health clinic-based hepatitis $C$ testing and linkage to care in Baltimore. J Viral Hepat 2016;23:366-374. doi: 10.1111/jvh.12507.

[31] Tohme RA, Xing J, Liao Y, Holmberg SD. Hepatitis C testing, infection, and linkage to care among racial and ethnic minorities in the United States, 2009-2010. Am J Public Health 2013;103:112-119. doi: 10.2105/AJPH. 2012.300858.

[32] Schoenbachler BT, Smith BD, Seña AC, Hilton A, Bachman S, Lunda M, et al. Hepatitis $C$ virus testing and linkage to care in North Carolina and South Carolina jails, 2012-2014. Public Health Rep 2016;131 Suppl 2:98-104. doi: $10.1177 / 00333549161310 S 215$.

[33] Bourgi K, Brar I, Baker-Genaw K. Health disparities in hepatitis C screening and linkage to care at an integrated health system in southeast Michigan. PLoS One 2016;11:e0161241. doi: 10.1371/journal.pone.0161241.

[34] Konerman MA, Thomson M, Gray K, Moore M, Choxi H, Seif E, et al. Impact of an electronic health record alert in primary care on increasing hepatitis c screening and curative treatment for baby boomers. Hepatology 2017;66: 1805-1813. doi: 10.1002/hep.29362.

[35] de la Torre AN, Castaneda I, Ahmad M, Ekholy N, Tham N, Herrera IB, et al. Audio-computer-assisted survey interview and patient navigation to increase chronic viral hepatitis diagnosis and linkage to care in urban health clinics. J Viral Hepat 2017;24:1184-1191. doi: 10.1111/jvh.12744.

[36] Patel RC, Vellozzi C, Smith BD. Results of hepatitis C birth-cohort testing and linkage to care in selected U.S. sites, 2012-2014. Public Health Rep 2016; 131 Suppl 2:12-19. doi: 10.1177/00333549161310S203.

[37] Coyle C, Viner K, Hughes E, Kwakwa H, Zibbell JE, Vellozzi C, et al. Identification and linkage to care of HCV-infected persons in five health centers Philadelphia, Pennsylvania, 2012-2014. MMWR Morb Mortal Wkly Rep 2015; 64:459-463.

[38] Akyar E, Seneca KH, Akyar S, Schofield N, Schwartz MP, Nahass RG. Linkage to care for suburban heroin users with hepatitis $C$ virus infection, New Jersey, USA. Emerg Infect Dis 2016;22:907-909. doi: 10.3201/eid2205.151980.
[39] Kronfli N, Linthwaite B, Kouyoumdjian F, Klein MB, Lebouché B, Sebastiani G, et al. Interventions to increase testing, linkage to care and treatment of hepatitis $\mathrm{C}$ virus ( $\mathrm{HCV}$ ) infection among people in prisons: A systematic review. Int J Drug Policy 2018;57:95-103. doi: 10.1016/j.drugpo.2018.04.003.

[40] Zuckerman A, Douglas A, Nwosu S, Choi L, Chastain C. Increasing success and evolving barriers in the hepatitis $C$ cascade of care during the direct acting antiviral era. PLoS One 2018;13:e0199174. doi: 10.1371/journal.pone.0199174.

[41] Trooskin SB, Poceta J, Towey CM, Yolken A, Rose JS, Luqman NL, et al. Results from a geographically focused, community-based HCV screening, linkage-to-care and patient navigation program. J Gen Intern Med 2015; 30:950-957. doi: 10.1007/s11606-015-3209-6.

[42] Islam MM, Topp L, Conigrave KM, White A, Reid SE, Grummett S, et al. Linkage into specialist hepatitis $C$ treatment services of injecting drug users attending a needle syringe program-based primary healthcare centre. J Subst Abuse Treat 2012;43:440-445. doi: 10.1016/j.jsat.2012.07.007.

[43] Miller LS, Rollin F, Fluker SA, Lundberg KL, Park B, Quairoli K, et al. High-yield birth-cohort hepatitis $C$ virus screening and linkage to care among underserved African Americans, Atlanta, Georgia, 2012-2013. Public Health Rep 2016;131 Suppl 2:84-90. doi: 10.1177/00333549161310S213.

[44] World Health Organization. Global health sector strategy on viral hepatitis 20162021. Available from: https://apps.who.int/iris/bitstream/handle/10665/ 246177/WHOHIV-2016.06-eng.pdf;jsessionid=BDB9D6116C68A2E10213BD8CAB2F2E39?sequence $=1$. Accessed June 2016.

[45] World Health Organization. Global Hepatitis Report 2017. Available from: https://apps.who.int/iris/bitstream/handle/10665/255016/9789241565455eng.pdf?sequence $=1$.

[46] Mehta D, Mccombs J, Sanchez Y, Marx S, Sammy S. Effectiveness of hepatitis $C$ virus screening laws in United States: Evidence from paid claims data from 2010 to 2016. J Hepatol 2018;68:S177-S178. doi: 10.1016/S0168-8278 (18)30566-X.

[47] Morse A, Barritt AS 4th, Jhaveri R. Individual state hepatitis C data supports expanding screening beyond baby boomers to all adults. Gastroenterology 2018;154:1850-1851.e2. doi: 10.1053/j.gastro.2018.02.035.

[48] Day E, Hellard M, Treloar C, Bruneau J, Martin NK, Øvrehus A, et al. Hepatitis $C$ elimination among people who inject drugs: Challenges and recommendations for action within a health systems framework. Liver Int 2019;39:2030. doi: $10.1111 /$ liv.13949. 